\title{
Pengaruh Earning Per Share dan Deviden Per Share terhadap Harga Saham
}

\author{
Irma Nurjanah* \\ Prodi Akuntansi, Fakultas Ekonomi dan Bisnis, Universitas Islam \\ Bandung, Indonesia. \\ *irmanurjanahss@gmail.com
}

\begin{abstract}
This study aims to examine the effect of Earning Per Share and Deviden Per Share on stock prices. The object of research used in this research is earning per share, deviden per share, stock prices. The subject in this study is a manufacturing company in the consumer goods industry sector which is listed on the Indonesian Stock Exchange (IDX). The research method used is descriptive and verification with a quantitative approach. This study uses secondary data with a purposive sampling method with a sample of 20 manufakturing companies in the consumer goods industry listed on the Indonesian Stock Exchange for the 2017-2019 observation period or 78 observations. Hypothesis testing in this study using multiple linear regressions analysis. From the results of the tests carried out, the results showed that Earning Per Share and Deviden per share had and effect on stock prices. Suggestions for further researchers are to add independent variables such as Debt Equity Ratio (ROA), Net Profit Margin (NPM), Price Earning Ratio (PER).
\end{abstract}

Keywords: Earning Per Share, Deviden Per Share, Stock Price

Abstrak. Penelitian ini bertujuan untuk menguji pengaruh earning per share dan deviden per share terhadap harga saham. Objek penelitian yang digunakan dalam penelitian ini adalah earning per share, deviden per share, harga saham. Subjek dalam penelitian ini adalah perusahaan manufaktur yang terdaftar di Bursa Efek Indonesia (BEI). Metode penelitian yang digunakan adalah deskriptif dan verifikatif dengan pendekatan kuatitatif. Penelitian ini menggunakan data sekunder dengan metode purposive sampling dengan sampel sebanyak 26 perusahaan manufaktur yang terdaftar di Bursa Efek Indonesia untuk rentang waktu pengamatan 2017-2019 atau sebanyak 78 pengamatan. Pengujian hipotesis dalam penelitian ini menggunakan analisis regresi linear berganda. Dari hasil pengujian yang dilakukan, hasil penelitian menunjukkan bahwa earning per share dan deviden per share berpengaruh terhadap harga saham. Saran bagi peneliti selanjutnya yaitu menambah variabel independen seperti Debt Equity Ratio (ROA), Net Profit Margin (NPM), Price Earning Ratio (PER)

Kata Kunci: Earning Per share, Deviden Per Share, Harga Saham 


\section{A. Pendahuluan}

Pasar modal ialah tempat yang sangat efisien bagi memesatkan pembangunan sesuatu negara sebab pasar modal ialah tempat yang bisa merubah pengumpulan dana untuk jangka panjang oleh masayarakat buat dibagikan ke sektor- sekt0r komersil. Pasar modal ialah alternatif yang bisa dipergunakan perusahaan untuk memperoleh dana yaang diperlukan meski disaat ini banyak seksali yang sediakan pinjamann namun seluruh itupun dapat terhambay sebab rataratayang dipunyai oleh perusahan tersebut. Investor juga mengharapkaan dana yang akan digunakan bisa membagikan hasil.(Indah\&parlia, 2017).

Harga saham ialah salah satu indikator berarti untuk investor untuk memperhitungkan keberhasilan pengelolaan industri masa yang hendak tiba (Efendi\&Ngatno, 2018). Apabila harga saham sesuatu perusahaan senantiasa hadapi peningkatann, maka dari itu investor ataupun calon yang akan menjadi investor memperbaiki jika perusahaan sukses dalam pengelolaan usahany. sedangkan kebalikannya apabila harga saham sesuatu perusahaan terus menjadi menyusut sehingga investorpun hendak menilai jika industri tersebut akan menghadapi kondisi yang tidak baik. Sebab keyakinan investor akan sangat bermanfaat untuk emiten.

Permasalahan harga saham sudah banyak terjadi, Seperti yang dinyatakan oleh Analis Sekuritas Stevanus Juanda bahwa Sector Barang Konsumsi menekan IHSG rendah 0, 22\% Pada level 1. IHSG pada tahap 1 perdagangan yang terkoreksi sebesar $0,22 \%$ ke tingkat 6.533,32. Penurunan IHSG pada hari ini paling utama yaitu oleh penilaian pada sector barangg konsumsi yaitu sebesar 0,33\% serta manufactur anjlok turun 0,54\%. Investor melepaskan saham- saham di Sector Barang Konsumsii serta Manufcktur sesudah Bank Indonesia menyampaikan hasil kepercayaankepada konsumen.

Kasus harga saham yang lain yang dinyatakan oleh Analis Paramitra Alfa Sekuritass Evaan Fajrin jika Sejak pertama tahun sampai dikala ini atau secara year to date( ytd), diagram harga saham industri barang konsumsi( consumer goods) menurun $12,68 \%$. Penyusutan sector ini diakibatkan oleh saham, emiten roko yang turun lumayan banyak, karena sentimeen negatiff berbentuk rencama peningkatan tarif cukaii sebesar $23 \%$ pada 2020.

Ada pula peningkatan harga saham yang dinyatakan oleh Analis NH Korindo Sekuritas Indonesia Putu Chantiika Putri indeks sektor barang konsumsi cuma terkoreksi 5, 5\% semenjak dini tahun, di bandingkan dengan indeks sektor properti yang ambles sampai 34, 8\% serta indeks aneka industri yang turun sampai 29, 55\% secara ytd. Peningkatan tersebut di karenakan sedikitnya koreksi yang terjalin pada indeks sektor barang konsumsi yang menampilkan jika saham- saham di sektor consumer good memanglah cenderung lebih resilient( kuat) di tengah keadaan pasar semacam ini. Perihal ini pula jadi salah satu pertimbangan pelaku pasar buat mengkoleksi saham- saham di sektor consumer.

Harga saham dapat di pengaruhi oleh beberapa factor fundamental seperti Earningg Per Shre (EPS) serta Deviden Per Share (DPS ), aspek awal yang akan pengaruhi harga saham ialah Earning Per Shre (EPS). Menurut Tandelilin, Eduardus(2010: 374) Earningg Per Shre (EPS) ialah rasio yang akan menampilkan seluruh kruntungan untuk tiap saham. Rasio kedua yang pengaruhi harga saham ialah Deviden Per Share (DPS). Dividen per shre, yaitu akan membagikan cerminan mengenakan seberapa besar keuntungan yang akan di bagikan mengenai wujud dividen untuk pemegang saham bagi masing- masing lembar saham. Tandelilin (2010: $384)$.

Bersumber pada latar belakang permasalah itu peneliti teliti, bahwa yang selaku rumusan masalah dalam penelitian ini yakni yaitu:

1. Bagaimana Earning Per Share (EPS) berpengaruh terhadap harga saham pada perusahaan manufactur sector industry barang konsumsi di Bursa Efek Indonesia?

2. Bagaimana Deviden Per Share (DPS) berpengaruh terhadap harga saham pada perusahaan manufaktur sector industry barang konsumssi di Bursa Efec Indonesia?

Selanjutnya, berdasarkaan pada identifiikasi masalah diatas, yang penelitian inilakukan dengan tujuan yaitu:

1. Untuk mencari tahu pengaruh Earning Per Share (EPS) terhadap harga saham di perusahaan manufaktur sector industryi barang konsumsii yang terdapat di BEI

2. Untuk mencari tahu pengaruh Deviden Per Share (DPS) terhadap harga saham di 
78 | Irma Nurjanah.

perusahaan manufaktur sector industry barang konsumsi yang terdapat di BEI

\section{B. Metodologi Penelitian}

Metode yang digunakan menggunakan metode verifikatif dengan pendekatan kuantitatif. karena untuk menguji hipotesis pengaruh debt to equity ratio dan earning per share terhadap harga saham pada perusahaan manufaktur yang terdaftar di Bursa Efek Indonesia (BEI). Sumber data menggunakan data sekunder yang sudah diolah oleh perusahaan dalam bentuk laporan keuangan dengan populasi sebanyak 154 perusahaan manufaktur. Teknik pengambilan sampel menggunakan non probability dengan teknik purposive sampling yang menghasilkan 70 perusahaan manufaktur. Adapun pengujian hipotesisnya yaitu Uji Asumsi klasik, Uji Simultan (Uji F), Uji Parsial (Uji t), Uji Regresi Linier Berganda dan Koefisiensi Determinasi

\section{Hasil Penelitian dan Pembahasan}

Hasil Penelitian Instrumen

Tabel 1. Hasil analisis regresi linear berganda

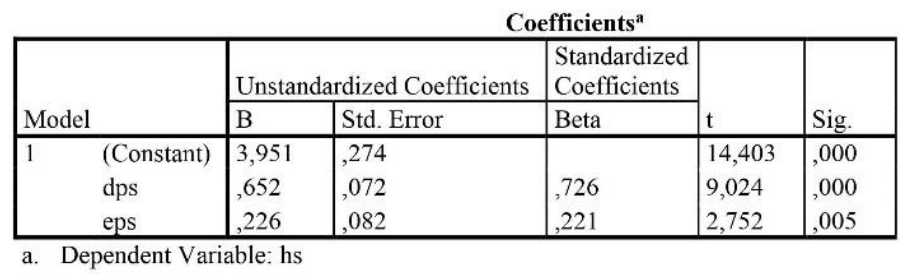

Berdasarkan Tabel 1 diatas , maka didapatlah persamaan regresi linear berganda sebagai berikut:

$$
\text { Harga Saham = 3,951 + 0,652Dps + 0,226Eps + e }
$$

Keterangan :

1. nilai konstanta $(\alpha)$ sebesar 3,951 maka variabel independent (Earning Per Share dan Deviden Per Share) adalah 0 maka variabel Harga Saham akan bernilai konstanta yaitu 3,951 .

2. nilai koefisiens regresi variable sebesar 0,652 menunjukan bahwa DPS mengalami peningkatan maka diprediksikan harga saham meningkat sebesar 0,652 .

3. nilai koefisiens regresi variable sebesar 0,226 menunjukan jika EPS meningkat maka dari itu diprediksikaan harga saham akan meningkat sebesar 0,226

Tabel 2. Hasil Uji Simultan (Uji f)

\begin{tabular}{|c|c|c|c|c|c|c|}
\hline \multicolumn{7}{|c|}{ ANOVA $^{a}$} \\
\hline Model & & \begin{tabular}{|l|l} 
Sum of \\
Squares
\end{tabular} & $\mathrm{df}$ & Mean Square & $\mathrm{F}$ & Sig. \\
\hline 1 & $\begin{array}{l}\text { Regression } \\
\text { Residual } \\
\text { Total }\end{array}$ & $\begin{array}{l}95,694 \\
22,450 \\
118,143\end{array}$ & $\begin{array}{l}2 \\
63 \\
65\end{array}$ & $\begin{array}{l}47,847 \\
, 356\end{array}$ & 134,271 &, $000^{\mathrm{b}}$ \\
\hline
\end{tabular}

Bersumber pada tabel di atas yang menggambarkan hasil Uji Simultan didapat Fhitung sebesar 134,271 dengan nilai signifikans yang sebesar $0.000 \mathrm{~b}$ lebih rendah dari timgkat yang signifikan 0.05 , perihal ini menunjukkan jika penelitian ini juga dapat digunakan untuk pengujian antara variable Earning Per Share serta Deviden Per Share terhadap HargaSaham. Dengan demikkian model penelitiani yang peneliti ajuukan dapat dilanjutkan untuk pengujian berikutnya. 
Tabel 3. Hasil Uji Parsial (Uji t)

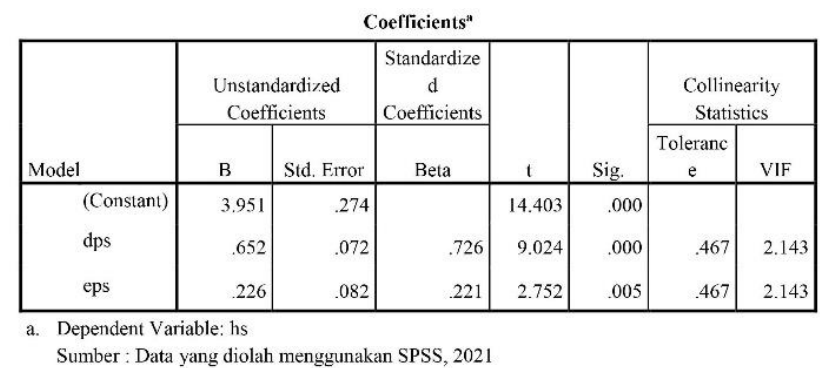

1. Pengaruh Earning Per Share terhadap Harga Saham

Bersumber pada tabel 3 diatas, hasil pengujian hipotesis EPS memiliki nilai signifikansi sebesar 0,005 ataupun lebih kecil dari 0,05 maksudnya Ho ditolak serta Ha diterima, hingga bisa disimpulkan kalau Earning Per Share berpengaruh signifikan terhadap harga saham pada perusahaan manufactur sector industry barang konsumsi yang terdaftar di BEI pada periode 2017- 2019.

2. Pengaruh Deviden Per Share terhadap Harga Saham

Bersumber kepada tabel 3 diatas, hasil pengujian hipotesis Deviden Per Share memiliki nilai signifikansi sebesar 0,000 ataupun lebih kecil dari 0,05 maksudnya Ho ditolak serta Ha diterima, hingga bisa disimpulkan kalau Deviden Per Share berpengaruh signifikan terhadap harga saham kepada perusahaan manufaktur sektor industry barang konsumsi yang terdaftar di Bursa Efek Indonesia pada periode 2017-2019.

Tabel 4. Hasil Uji Koefisien Determinasi $\left(\mathrm{R}^{2}\right)$

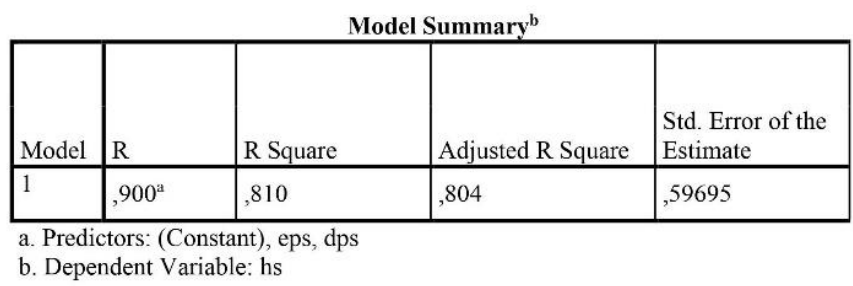

Bersumber pada hasil uji analisis pada tabeli diatas menunjukan jika nilai koefisien determinasi( R2) ialah sebesar 0, 81 ataupun $81 \%$. Perihal ini menampilkan makna jika Harga Saham mempengaruhi kepada Earning Per Share serta Deviden Per Share sebesar 0, 81. Sebaliknya sisanya $(100 \%-81 \%=29 \%)$ dipengaruhi oleh variabel- variabel yang lain.

\section{Pengaruh Earning Per Share terhadap Harga Saham}

Bersumber pada hasil uji hipotesis membuktikan jika Earniing Per Share( EPS) berpengaruh kepada harga saham dari perusahaan manufaktur sektor industry barang konsumsi yang terdaftar di BEI tahun 2017- 2019. Perihal tersebut membuktikan jika hipotesis yang diajukan peneliti diterima.

Hasil pengujian uji t, menunjukakan kalau EPS berpengaruh terhadap harga saham dengan hasil pengujian hipotesis serta nilai signifikans sebesar 0,005 $<0,05$ maksudnya, HO ditolak Ha di terima. Sebaliknya dilihat dari hasil dari persamaan regresi linier berganda, EPS mempunyai koefisiens regresi sebesar 0, 226, yang maksudnya bila Earning Per Share bertambah serta variabel yang lain konstan, hingga Earning Per Share di perusahaan manufactur sector industry dan barang konsumsi yang terdaftar di Bursa Efec Indonesia ( BEI) sepanjang periode 2017- 2019 hendak bertambah sebesar 0, 226

Oleh sebab itu, bisa disimpulkan kalau Earning Per Share berpengaruh signivikan terhadap harga saham pada perusahaam manufactur sector industry barang konsumsi yang terdapat di Bursa Efek Indonesia( BEI) tahun 2017- 2019. Perihal ini pula didukung oleh riset yang dilakukkan oleh Emma Lilianti( 2018) bahwa EarningPer Share( EPS) memiliki pengaruh signifikan terhadap harga saham. 
80 | Irma Nurjanah.

\section{Pengaruh Deviden Per Share terhadap Harga Saham}

Bersumber dari hasil uji hipotesis membuktikan jika Deviden PerShare( EPS) berpengaruh terhadap harga saham pada perusahaan manufactur sekcor industry barang konsumsi yang terdaftar di BEI periode 2017- 2019. Perihal tersebut membuktikan jika hipotesis yang diajukan peneliti diterima.

Hasil uji t, menunjukakan jika DPS berpengaruh kepada harga saham dengan pengujian hipotesis serta nilai signifikansi sebesar 0,005 $<0,05$ maksudnya, $\mathrm{H}_{\mathrm{o}}$ dit0lak Ha diterima. Sebaliknya dilihat dari hasil persamaan regresi linier berganda, Deviden Per Share mempunyai koefisien regresi sebesar 0, 625, yang maksudnya bila Deviden Per Share bertambah serta variabel yang lain konstan, hingga Deviden Per Share di perusahaan manufaktur sector industry serta barang konsumsi yang terdapat di Bursa Efek Indonesia( BEI) sepanjang periode 20172019 hendak bertambah sebesar 0, 625 .

Oleh sebab itu bisa disimpulkan jika Deviden Per Share berpengaruh terhadap harga saham pada perusahaan manufaktur sector industry barang konsumsii yang terdapat di Bursa Efek Indonesia (BEI) sepanjang tahun 2017- 2019. Maksudnya, bila Dividend Per Share yang didapatkan naik pasti saja inipun hendak membuat investor terdorong buat membeli saham industri tersebut. Dengan banyaknya saham yang dibeli hingga harga saham perusahaan tersebut hendak tingi.

Hal ini juga didukung oleh penelitian Wiwik Nur Alfiah (2017) tentang pengaruh dps terhadap harga saham menunjukkan bahwa variablle Deviden PerShare berpengaruh signifikan terhadap harga saham.

\section{Kesimpulan}

Bersumber dari hasil yang di teliti serta ulasan mengenai penggaruh Earning Per Share dan Deviden Per Shareterhadap Harga Saham pada perusahaan manufaktur sector industry barang konsumsi yang terdapat di Bursa Efek Indonesia pada tahun 2017- 2019 maka pada akhirr penelitian bisa ditarik kesimpulann sebagai berikut :

1. Earning Per Share berpengaruh terhadap Harga Saham yang artinya, semakin tingi nilaii Earning Per Shre, maka akan semakin tingi keuntungann yang bakal di peroleh investor bagi setiap lembar saham nya.

2. Deviden Per Shre berpengaruh terhadap Harga Saham.yang artinya, semakin tingi Deviden yang akan di bayarkan perusahaan maka yang akan meningkatkan permintan saham sehinga harga saham bakal mengalami kenaikan.

\section{Acknowledge}

Penulis mengucapkan terima kasih kepada seluruh pihak yang telah membantu dan mendukung dalam memberikan data maupun informasi untuk menyelesaikan penelitian ini.

\section{Daftar Pustaka}

[1] Darmadji, Tjiptono, dan Fakhruddin. (2012). Pasar Modal Di Indonesia. Edisi. Ketiga.zJakarta : Salemba Empat.z

[2] Efendi, F. M., \& Ngatno, N. (2018). Pengaruh Return On Assets (ROA) Terhadap Harga Saham dengan Earning PerShare (EPS) sebagai Intervening (Studi Kasus pada Perusahaan Sub Sektor Tekstil dan Garmen yang terdaftar di Bursa Efek Indonesia Periode 2013-2016). Jurnal Administrasi Bisnis, 7(1)

[3] Hartono, Jogiyanto. (2003). Teori Portofollio dan Analisis Investasi, Edisi kelima. Yogyakarta: BPEE

[4] Indah, P. (2017). Pengaruh Earning per Share Terhadap Harga Saham. Jurnal Penelitian Ekonomi Akuntansi. Vol.1 No.1 Hlm:72-81

[5] Lilianti, E. (2018) Pengaruh Dividend Per Share (DPS) dan Earning Per share (eps) terhadap Harga Saham pada perusahaan sub sektor Farmasi di Bursa Efek Indonesia (BEI). Jurnal Penelitian Ekonomi Akuntansi. Volume 3 Nomor 1

[6] Lukman, S. (2009). Manajemen Keuangan Perusahaan. Jakarta: PT Raja grafindo Persada. 
[7] Tandelilin, Eduardus. 2010. Portofolio dan Investasi: Teori dan Aplikasi. Yogyakarta: Kanisius. .

[8] Wiwik, Alfiah. (2017). PENGARUH DPS, EPS, NPM, R0A TERHADAP HARGA SAHAM PERUSAHAAN PERBANKAN DI BEI. Jurnal Ilmu dan Riset Manajemen, Volume 6, Nomor 9 